\title{
Article \\ Effects of COVID-19 Pandemic on the Bulgarian Stock Market Returns
}

\author{
Lilko Dospatliev ${ }^{1}$, Miroslava Ivanova ${ }^{2, *}$ (D) and Milen Varbanov ${ }^{3}$ \\ 1 Department of Pharmacology, Animal Physiology and Physiological Chemistry, \\ Faculty of Veterinary Medicine, Trakia University, 6000 Stara Zagora, Bulgaria; 1kd@abv.bg \\ 2 Department of Informatics and Mathematics, Faculty of Economics, Trakia University, \\ 6000 Stara Zagora, Bulgaria \\ 3 Department of Language and Specialized Training, Medical University—Pleven, 5800 Pleven, Bulgaria; \\ milen.varbanov@mu-pleven.bg \\ * Correspondence: mivanova_tru@abv.bg
}

Citation: Dospatliev, L.; Ivanova, M.; Varbanov, M. Effects of COVID-19

Pandemic on the Bulgarian Stock

Market Returns. Axioms 2022, 11, 94.

https://doi.org/10.3390/

axioms11030094

Academic Editor: Sidney A. Morris

Received: 7 January 2022

Accepted: 22 February 2022

Published: 24 February 2022

Publisher's Note: MDPI stays neutral with regard to jurisdictional claims in published maps and institutional affiliations.

Copyright: (c) 2022 by the authors. Licensee MDPI, Basel, Switzerland. This article is an open access article distributed under the terms and conditions of the Creative Commons Attribution (CC BY) license (https:// creativecommons.org/licenses/by/ $4.0 /)$.

\begin{abstract}
The purpose of this paper is to provide the first empirical research analysing the effects of the COVID-19 pandemic on the Bulgarian stock market before its onset and in the four pandemic waves. For this purpose, we used a fixed effect panel data regression model for the stock returns of 23 companies listed on the Bulgarian Stock Exchange from 2 January 2020 to 16 November 2021. The study showed that the growth rate of COVID-19 deaths per day in Bulgaria had a negative effect on the stock returns and had the strongest influence on them in the fourth pandemic wave. In addition, our results showed that stock returns in healthcare, IT, utilities, and real estate sectors were negatively affected before the COVID-19 pandemic while the first COVID-19 pandemic wave had a positive effect on healthcare and consumer staples sectors. During the second COVID-19 wave, the stock returns of the IT sector had a positive effect, while Utilities sector had a negative effect. The third COVID-19 wave had a positive effect on industrials and consumer staples sectors, while healthcare, real estate, and IT sectors showed a negative effect. During the fourth COVID-19 wave, the stock returns of the IT sector had a positive effect and consumer staples sector had a negative effect.
\end{abstract}

Keywords: stock return; COVID-19; pandemic wave; panel data; fixed effect regression model; Bulgaria

\section{Introduction}

On 31 December 2019, a cluster of cases of pneumonia from an unknown cause was first detected in Wuhan City, Hubei Province of China [1]. Within days, the virus caused complications in the respiratory tract of the infected persons, causing an increase in the number of deaths [2]. This virus was given the name Novel Human Coronavirus (SARS-CoV-2), known as COVID-19 [3]. On 30 January 2020, the World Health Organisation acknowledged COVID-19 as a pandemic due to its quick spread $[4,5]$. Despite the on-going efforts of governments, the virus has spread almost everywhere in the world.

Bulgaria recorded the first case of COVID-19 on 8 March 2020. The first COVID19 pandemic wave (March-June 2020) did not hit Bulgaria to the same extent as other European countries, such as Italy, Spain, Belgium, and the United Kingdom. The severe second pandemic wave in Bulgaria occurred in November-December 2020. Based on 14-day statistics, Bulgaria had the third-highest mortality rate of COVID-19 and was in 13th place in morbidity within the European Union, said the Chief State Health Inspector on 19 November 2020 [6]. The third wave covered the period March-April 2021, and the fourth began on 25 October 2021. On 9 November 2021, Bulgaria reported a record number of daily coronavirus deaths as Bulgaria was the EU's least vaccinated country [7].

Up to 16 November 2021, COVID-19 triggered 658,870 confirmed cases and 27,180 deaths in Bulgaria [8]. 
The economic and financial consequences of the COVID-19 pandemic and its precautionary impositions have been visibly detrimental for most goods and service industries globally [9]. This economic downturn is far worse than that of the financial crisis in 2008 and it may be the worst recession since the Great Depression [10].

The Bulgarian Stock Exchange (BSE) suffered in 2020 as the COVID-19 pandemic and the drop in oil prices caused by the Russia-Saudi Arabia price war created "the perfect storm". The SOFIX index, which tracks the performance of the 15 blue-chip stocks listed on the BSE, reached its lowest level only a few days after the first confirmed case of COVID-19 in Bulgaria (19 March 2020), when it sank to 405.8 points. The wider BGBX40 and BGTR30 indices saw slimmer decreases in 2020 - of $9.34 \%$ and $3.31 \%$, respectively, while the BGREIT index thrived and registered a 5.89\% rise, setting multiple record-high closes along the way.

The purpose of this paper is to provide the first empirical research analysing the effects of COVID-19 pandemic on the Bulgarian stock market before its onset and the first, second, third, and fourth pandemic waves.

For this purpose, we will analyse the evolution of the stock returns of 23 Bulgarian companies under the influence of the variables reflecting the spread of COVID-19 in Bulgaria (the growth rate in confirmed COVID-19 cases per day, growth rate in COVID-19 deaths per day), as well as of the variables related to the period before the COVID-19 pandemic in Bulgaria and the four pandemic waves. In addition, the analysis will include the variables describing some firm-specific characteristics (market capitalisation and priceto-book ratio). The fixed effect panel regression approach will be used. The data have been analysed over the period from 2 January 2020 to 16 November 2021.

To the best of our knowledge, our study is the only one that uses a Bulgarian stock market dataset to test the effects of the COVID-19 pandemic on stock returns. Our results show that the growth rate in confirmed COVID-19 cases per day, the growth rate in COVID19 deaths per day, COVID-19 period variables, and price-to-book ratio of company are positively correlated with the stock returns. Our contributions add to the growing body of literature on the interplay of COVID-19 pandemic and financial markets [11-15].

Our results also show the negative effects that the growth rate in COVID-19 deaths per day had on the Bulgarian stock market returns. In addition, our results show a heterogeneous response of stock returns to the COVID-19 pandemic across sectors.

Furthermore, we will present the relevant results found in the literature in the field, the analysed data, the research methods, and the empirical results. The article also comprises the discussion and conclusions regarding the obtained results.

\section{Literature Review}

The occurrence of the COVID-19 pandemic has had harmful effects on worldwide markets [16,17], being expected to be the largest economic shock in human history [18]. According to the theory of behavioral finance, emergency events will affect the basic value of stocks and the psychological and behavioral responses of investors, which will further affect stock prices [19]. Batrancea [20] focused on the link between fiscal pressure and financial equilibrium for energy companies listed on the stock exchange market.

Yan [21] investigated the Chinese stock markets' reaction to COVID-19 and found that stock prices fell sharply with the lockdown of Wuhan city, and stock returns then reversed in subsequent periods. The rapidity with which COVID-19 dispersed around the world produced a panic in international financial markets [22] and raised stock market crash risk [23]. Samitas et al. [24] examines the impact of the COVID-19 pandemic on 51 major stock markets, both emerging and developed. This research shows instant financial contagion a result of the lockdown and the spread of the novel coronavirus. Liu et al. [25] found that COVID-19 has made greater impacts on the stock market than the bond market in 26 countries or regions while Rehman et al. [26] concentrate on the stock markets of the G7 countries. Li et al. [27] examined the impact of the COVID-19 pandemic on G20 stock and found that the total volatility connectedness increases significantly during the COVID-19 crisis. 
Chowdhury et al. [28] claimed that European financial markets were the most affected. In the same vein, Youssef et al. [29] noticed that European equity markets, excepting Italy, spread more spillovers to other financial markets than they obtained, mainly through the coronavirus outburst. Szczygielski et al. [30] showed that pandemic insecurity affected nearly all territories via smaller returns and heightened market volatility.

Nian et al. [31] examined the time-frequency co-movement impact of COVID-19 on the U.S. and China stock markets, and found that, during the first phase of the COVID19 outbreak, stock markets experienced extreme volatility due to investors' pessimistic expectations. Zehri [32] found evidence that the effect of COVID-19 in the U.S. spilled over to China, Japan, and South Korea. Zhang and Mao [33] investigated the cross-market spillover effect between the Chinese and U.S. stock index returns, and the markets' volatility from the impact of the COVID-19 pandemic spreading in China and found that there was an asymmetric transmission of return shocks to a stronger degree from the Chinese stock market to the U.S. market rather than from the opposite direction.

The research by Camba and Camba Jr. [34] documented the negative impact of the COVID19 daily infection rate on the Philippine stock market index. The negative and significant impact of confirmed cases on stock market performance is supported by other studies, such as [35-39].

Singh and Shaik [40] found that announcements by the World Health Organisation regarding COVID-19 on the new cases and deaths caused a significant decline on nine different global stock market indices. Ashraf [41] also found the negative impact of both confirmed cases and deaths because of COVID-19 on stock market returns in 64 countries. The increase in number of confirmed cases and deaths had a significant and positive effect toward market volatility [42]. Udeaja and Isah [43] showed that the number of confirmed cases rather than the number of deaths tend to be responsible for the declining stock returns in Africa during the pandemic phase of the COVID-19 outbreak. Bahrini and Filfilan [44] confirmed the negative impact of COVID-19 deaths on stock returns in Gulf Cooperation Council Countries.

In addition, some studies focused on the performance of the stock in different economic sectors. Mazur et al. [45] found that the return of healthcare, food, natural gas, and software sectors performed well during the pandemic; however, crude petroleum, real estate, entertainment, and hospitality sectors fell sharply, and they had great volatility. In [46], it was found that the hardest-hit sector on Vietnam's stock markets during the COVID-19 pandemic was the financial sector. In [47] it was found that health care equipment \& service daily return, food and beverage daily return, food \& staples retailing daily return, telecommunication daily return, transportation daily return, and commercial \& professional services daily return have had high contributions that are significantly positive to Saudi stock return. In [39], a negative coefficient was shown on property as well as trade, service, and investment. In [48-50], a mixed impact was found on each sector's stock performance.

\section{Methods and Results}

\subsection{Panel Data Source}

In the present study, we tracked down monthly closing prices of 23 of the largest and liquid companies listed on the Bulgarian Stock Exchange. The list of the companies, arranged in alphabetical order, is: Allterco AD, Althea Group Holdings Ltd, Advance Terrafund REIT, Albemarle Corporation, Sopharma Properties ADSITS, Sirma Group Holding AD, Bulgarian Real Estate Fund ADSITS, Bulgaria Stock Market, CEZ Distribution Bulgaria AD, Chimimport AD, Doverie United Holding PLC, EuroHold Bulgaria AD, First Investment Bank AD, Gradus $\mathrm{AD}$, Industrial Holding Bulgaria PLC, Monbat $\mathrm{AD}, \mathrm{M}+\mathrm{S}$ Hydraulic $\mathrm{AD}$, Sofia Commerce Pawn Brokerage AD, Sopharma Trading AD, Speedy AD, Stara Planina Hold AD, Trace Group Hold AD, and Zarneni Hrani Bulgaria AD.

This study was developed on the ground that the COVID-19 pandemic had shown a substantial effect on stock market trading and the Bulgarian stock market observed consistent volatility. An empirical association between the daily stock returns and COVID19 pandemic by controlling firm-specific factors were investigated during a time period 
from 2 January 2020 (the first day of operation of the Bulgarian Stock Market in 2020) to 16 November 2021 (taken as the data end date). The time zone of this study is divided into five phases: Before the COVID-19 pandemic in Bulgaria (between 2 January 2020 and 12 March 2021), the first wave of COVID-19 in Bulgaria (from 13 March 2020 to 14 May 2020), the second wave (from 1 November 2020 to 31 December 2020), the third wave (from 1 March 2021 to 30 April 2021), and the fourth wave (from 25 October 2021 to 16 November 2021). The data of COVID-19 daily confirmed cases and daily deaths in Bulgaria were obtained from the website of the Humanitarian Data Exchange [51].

A panel data approach was adopted to investigate the effects of the COVID-19 pandemic on the Bulgarian stock market returns, consisting of a number of firms (23), time period (10,787 working days), and the variables under study. A total of 248,101 firms' observations were recorded for each variable during the specified period. Panel data spread the modelling possibilities and provided more variation and less collinearity among the variables under study [52]. According to [53], panel data also lead to the presence of a greater degree of freedom and thereby increased the model efficiency. Furthermore, the panel data regression was better in identifying the relationships between independent and dependent variables as well as reducing the errors, such as heteroskedasticity, estimation bias, and multicollinearity [54-56].

\subsection{Panel Data Regression Models}

Based on the panel data regression approach, we analysed the effects of the COVID19 pandemic on the Bulgarian stock market returns while controlling some firm-specific characteristics as market capitalisation and the price-to-book ratio.

Bearing that in mind [46], we implemented two dummy variables $\left(D_{B F C 19}\right.$ for the period before the COVID-19 pandemic in Bulgaria between 2 January 2020 and 12 March 2020 and $D_{C 19}$ 1st , for the general state of emergency in Bulgaria from 13 March 2020 to 14 May 2020) for evaluating the differences of stock returns in these two periods. Furthermore, considering the specific situation in Bulgaria comprising different periods of the COVID-19 pandemic in 2020 and 2021 and the fact that Bulgaria had the highest COVID-19 mortality rate in the European Union for these periods, we introduced three more dummy variables $\left(D_{C 19}\right.$ 2nd for the period of the second wave of COVID-19 in Bulgaria from 1 November 2020 to 31 December 2020, $D_{\text {C19_3th }}$ for the third wave of COVID-19 from 1 March 2021 to 30 April 2021, and $D_{\text {C19_4th }}$ for the fourth wave of COVID-19 from 25 October 2021 to the date of our analysis (16 November 2021)) in order to examine the effects of the COVID-19 pandemic.

Undoubtedly, the COVID-19 pandemic has affected various economic sectors. However, a few sectors have seen an upsurge and this has affected the daily stock returns in a significant manner. In $[12,39,41,46,47,57,58]$, it was found that that various economic sectors significantly affect the stock returns. To assess the effect of different economic sectors (information technology, industrials, real estate, consumer staples, financial, utilities, and healthcare), we included dummy variables in panel data regression models in our research.

The panel regression models evaluated in this research are:

Model 1: Evaluating the effect of the COVID-19 pandemic on Bulgarian stock returns in each of one of the five periods:

$$
S R_{i, t}=\alpha_{0}+\alpha_{1} C C 19_{t-1}+\alpha_{2} D C 19_{t-1}+\alpha_{3} M C_{i, t-1}+\alpha_{4} P B_{i, t-1}+\alpha_{5} D_{\text {period }_{i, t}}+\epsilon_{i, t} .
$$

Model 2: Evaluating the effect of the COVID-19 pandemic on Bulgarian stock returns in various economic sectors:

$$
S R_{i, t}=\beta_{0}+\beta_{1} C C 19_{t-1}+\beta_{2} D C 19_{t-1}+\beta_{3} M C_{i, t-1}+\beta_{4} P B_{i, t-1}+\beta_{5} D_{\text {sector }_{i}}+\eta_{i, t} .
$$

Model 3: Evaluating the effect of the COVID-19 pandemic on Bulgarian stock returns in various economic sectors in each of one of the five periods:

$$
S R_{i, t}=\gamma_{0}+\gamma_{1} C C 19_{t-1}+\gamma_{2} D C 19_{t-1}+\gamma_{3} M C_{i, t-1}+\gamma_{4} P B_{i, t-1}+\gamma_{5} D_{\text {sector }_{i}} D_{\text {period }}+\theta_{i, t}
$$


where:

$S R_{i, t}$ is the stock return of company $i$ on day $t$, obtained by $S R_{i, t}=\ln \left(\frac{P_{i, t}}{P_{i, t-1}}\right)$, where $P_{i, t}$ is the closing stock price on day $t$ and $P_{i, t-1}$ is the closing stock price on day $t-1$;

$C C 19_{t-1}$ is the growth rate in confirmed COVID-19 cases per day in Bulgaria on day $t-1$;

$D C 19_{t-1}$ is the growth rate in COVID-19 deaths per day in Bulgaria on day $t-1$;

$M C_{i, t-1}$ is the natural logarithm of daily market capitalisation of company $i$ on day $t-1$;

$P B_{i, t-1}$ is the price-to-book ratio of company $i$ on day $t-1$;

$D_{\text {period }_{i, t}}$ is a dummy variable that presents whether the relevant day is in the period before the COVID-19 pandemic in Bulgaria (i.e., $D_{B F C 19}$ takes value 1 between 2 January 2020 and 12 March 2020, and 0 otherwise); in the first wave of the COVID-19 pandemic in Bulgaria (i.e., $D_{\text {C19_1st }}$ takes value 1 between 13 March 2020 and 14 May 2020, and 0 otherwise); in the second wave period (i.e., $D_{C 19} 2$ 2nd takes value 1 between 1 November 2020 and 31 December 2020, and 0 otherwise); in the third wave period (i.e., $D_{C 19 \_3 r d}$ takes value 1 between 1 March 2021 and 30 April 2021, and 0 otherwise); or during the fourth wave period (i.e., $D_{C 19 \_4 t h}$ takes value 1 between 25 October 2021 and 16 November 2021 (the date of our analysis) and 0 otherwise);

$D_{\text {sector }}$ is a dummy variable that presents whether the economics sector of company is information technology $\left(D_{I T}\right)$, industrials $\left(D_{\text {Industrials }}\right)$, real estate $\left(D_{\text {RealEstate }}\right)$, consumer staples $\left(D_{\text {ConsumerStaples }}\right)$, financial $\left(D_{\text {Financial }}\right)$, utilities $\left(D_{\text {Utilities }}\right)$, or healthcare $\left(D_{\text {Healthcare }}\right)$. If the dummy variable is equal to 1 then the company belongs to the respective sector, and it is equal to 0 in another cases;

$\epsilon_{i, t}, \eta_{i, t}$, and $\theta_{i, t}$ are the regression error terms.

The research hypotheses are formulated as follows:

Hypothesis 1 (H1). Negative effect of growth rate in confirmed COVID-19 cases per day on the return of the companies traded on the Bulgarian Stock Exchange.

Hypothesis 2 (H2). Negative effect of growth rate in COVID-19 deaths per day on the return of the companies traded on the Bulgarian Stock Exchange.

Hypothesis 3 (H3). The COVID-19 pandemic has a positive effect on the IT sector and negative effect on industrials, real estate, consumer staples, financial, utilities, and healthcare sectors.

\subsection{Panel Analytic Models}

Pooled regression model is one type of model that has constant coefficients, referring to both intercepts and slopes. For this model, researchers can pool all the data and run an ordinary least squares regression model. The fixed effect model is the differences across cross-sectional units that can be captured in differences in the constant term and the intercept term of the regression model varies across the cross sectional units. In this model, $\alpha_{j}$ is the intercept term that represents the fixed country effect. On the other hand, in the random effect model, the individual effects are randomly distributed across the cross-sectional units and in order to capture the individual effects, the regression model is specified with an intercept term representing an overall constant term [59].

\subsection{Statistical Tests}

\subsubsection{Augmented Dickey-Fuller Test}

The Augmented Dickey-Fuller test (ADF) tests the null hypothesis that a unit root is present in a time series sample. The alternative hypothesis is different depending on which version of the test is used, however it is usually stationarity or trend-stationarity. It is an augmented version of the Dickey-Fuller test for a larger and more complicated set of time series models. The augmented Dickey-Fuller (ADF) statistic, used in the test, is a negative number. The more negative it is, the stronger the rejection of the hypothesis that there is a unit root at some level of confidence [60]. 


\subsubsection{Maddala-Wu Test}

The Maddala-Wu panel unit root test [61] is a non-parametric test. It allows for heterogeneity across countries and does not require a balanced panel. The test is suitable to use when a mixture of stationary and non-stationary series in the group are included as an alternative hypothesis. It has comparatively higher power in distinguishing the null from the alternative hypothesis. The null hypothesis of non-stationarity of all the series within a specific panel is tested against the alternative of at least one stationary series.

\subsubsection{Hausman Test}

The Hausman test is a test for detects endogenous regressors in a regression model. The null hypothesis for this test is that individual random effects are exogenous.

In panel data analysis, the Hausman test [62] is used to differentiate between fixed effects model and random effects model in panel analysis. The null hypothesis is that the preferred model is random effects due to higher efficiency, while the alternate hypothesis is that the model is fixed effects.

\subsubsection{Variance Inflation Factor}

Variance Inflation Factors (VIF) measure the inflation in the variances of the parameter estimates due to collinearities that exist among the predictors. It is a measure of how much the variance of the estimated regression coefficient is "inflated" by the existence of correlation among the predictor variables in the model. A VIF of 1 means that there is no correlation among the k-th predictor and the remaining predictor variables, and hence the variance is not inflated at all. The general rule is that VIFs exceeding 4 warrant further investigation, while VIFs exceeding 10 are signs of serious multicollinearity requiring correction.

\subsubsection{Breusch-Pagan LM Test}

The Breusch-Pagan LM test [63] is used in panel data when the time dimension of the panel is larger than the cross-sectional dimension. The null hypothesis for this test is that residuals across entities are not correlated. The alternate hypothesis is that there is cross-sectional dependence.

\subsubsection{Breusch-Godfrey Test}

The Breusch-Godfrey test $[64,65]$ is a test for autocorrelation at higher orders. The null hypothesis is that there is no serial correlation of any order less than or equal to $p$. The alternative hypothesis is there exists autocorrelation at some order less than or equal to $p$. Since the test is based on the idea of Lagrange multiplier testing, it is sometimes referred to as an LM test for serial correlation.

\subsubsection{Breusch-Pagan Test}

The Breusch-Pagan test [66] is used to determine whether or not heteroscedasticity is present in a regression model. The test uses the following null hypothese: Homoscedasticity is present (the residuals are distributed with equal variance). The alternate hypothesis is there is heteroscedasticity (the residuals are not distributed with equal variance).

\subsection{Statistical Software}

All statistical computing and tests were performed with the statistical software $\mathrm{R}$ program version 4.0.3.

\subsection{Results}

Table 1 presents the descriptive statistics of the variables under study. The maximum daily stock return during the study period is $23.24 \%$ and the minimum is $-23.10 \%$. The highest growth rate in confirmed COVID-19 cases per day is $43.02 \%$ and the highest growth rate in COVID-19 deaths per day is $16.01 \%$. The maximum market capitalisa- 
tion during the same period is $22.11 \%$ and the minimum is $14.45 \%$. The maximum daily price-to-book ratio is $11.01 \%$ and the minimum is $0.01 \%$.

The skewness for the dataset is strictly positive with the highest value at 4.96 for the fourth pandemic wave and only one negative value of -0.47 for market capitalisation, similar to $[35,67,68]$. These positive results imply that the stocks would have frequent small gains and few extreme or significant losses.

The possibility of extreme returns (technically termed as kurtosis) for this dataset is strictly positive, similar to [15,69-74]. It is known that when data follows normal distribution, the kurtosis has a value of three. Most of our variables have a value greater than three, with the exception of $M S, D_{\text {Industrials }}, D_{\text {RealEstate }}, D_{\text {ConsumerStaples }}$, and $D_{\text {Financial }}$. A value greater than three have means of higher instances of abnormal returns, whereas a low value of kurtosis (less than three) implies fewer instances of abnormal returns.

Finally, all the variables have a positive number for the Jarque-Bera statistic and it is far from zero with a $p$-value less than $2.2 \times 10^{-16}$. Therefore, we reject the null hypothesis that the data are normally distributed, much like [15,35,72,74,75].

Table 1. Descriptive statistics of the variables from 2 January 2020 to 16 November 2021.

\begin{tabular}{|c|c|c|c|c|c|c|c|}
\hline Variable & Mean & St. Dev. & Max & Min & Skewness & Kurtosis & $\begin{array}{c}\text { Jarque-Bera } \\
\text { ( } p \text {-Value })\end{array}$ \\
\hline$S R$ & 0.0004 & 0.0416 & 0.2324 & -0.2310 & 0.1058 & 18.0702 & $\begin{aligned} & 146.6265 \\
< & 2.2 \times 10^{-16}\end{aligned}$ \\
\hline CC19 & 0.1539 & 1.6058 & 0.4302 & 0.0113 & 2.0327 & 3.4659 & $\begin{array}{c}14.5561 \\
<2.2 \times 10^{-16}\end{array}$ \\
\hline DC19 & 0.0410 & 1.9134 & 0.1601 & 0.0024 & 3.0001 & 12.5112 & $\begin{array}{c}94.0271 \\
<2.2 \times 10^{-16}\end{array}$ \\
\hline$M C$ & 1.8583 & 1.4139 & 0.2211 & 0.1445 & -0.4677 & 1.4439 & $\begin{array}{c}13.2853 \\
<2.2 \times 10^{-16}\end{array}$ \\
\hline$P B$ & 1.5686 & 1.7809 & 0.1101 & 0.0001 & 2.0411 & 4.5302 & $\begin{array}{c}6.7011 \\
<2.2 \times 10^{-16}\end{array}$ \\
\hline$D_{B F C 19}$ & 0.1045 & 0.3059 & 1.0000 & 0.0000 & 2.5865 & 4.6908 & $\begin{array}{c}4.1902 \\
<2.2 \times 10^{-16}\end{array}$ \\
\hline$D_{C 19 \_1 s t}$ & 0.0874 & 0.2825 & 1.0000 & 0.0000 & 2.9219 & 6.5384 & $\begin{array}{c}3.4538 \\
<2.2 \times 10^{-16}\end{array}$ \\
\hline$D_{C 19 \_2 n d}$ & 0.0874 & 0.2825 & 1.0000 & 0.0000 & 2.9219 & 6.5384 & $\begin{array}{c}3.4432 \\
<2.2 \times 10^{-16}\end{array}$ \\
\hline$D_{C 19 \_3 r d}$ & 0.0917 & 0.2886 & 1.0000 & 0.0000 & 2.8302 & 6.0113 & $\begin{array}{c}3.0620 \\
<2.2 \times 10^{-16}\end{array}$ \\
\hline$D_{C 19 \_4 t h}$ & 0.0363 & 0.1869 & 1.0000 & 0.0000 & 4.9631 & 22.6369 & $\begin{array}{c}2.7436 \\
<2.2 \times 10^{-16}\end{array}$ \\
\hline$D_{I T}$ & 0.0870 & 0.2818 & 1.0000 & 0.0000 & 2.9322 & 6.5989 & $\begin{array}{c}3.5003 \\
<2.2 \times 10^{-16}\end{array}$ \\
\hline$D_{\text {Industrials }}$ & 0.3478 & 0.4763 & 1.0000 & 0.0000 & 0.6391 & 1.5919 & $\begin{array}{c}1.8728 \\
<2.2 \times 10^{-16}\end{array}$ \\
\hline$D_{\text {RealEstate }}$ & 0.1304 & 0.3368 & 1.0000 & 0.0000 & 2.1950 & 2.8185 & $\begin{array}{c}2.2257 \\
<2.2 \times 10^{-16}\end{array}$ \\
\hline$D_{\text {ConsumerStaples }}$ & 0.1304 & 0.3368 & 1.0000 & 0.0000 & 2.1950 & 2.8185 & $\begin{array}{c}2.2257 \\
<2.2 \times 10^{-16}\end{array}$ \\
\hline$D_{\text {Financial }}$ & 0.2174 & 0.4125 & 1.0000 & 0.0000 & 1.3705 & 0.1217 & $\begin{array}{c}3.3826 \\
<2.2 \times 10^{-16}\end{array}$ \\
\hline$D_{\text {Utilities }}$ & 0.0435 & 0.2039 & 1.0000 & 0.0000 & 4.4778 & 18.0544 & $\begin{array}{c}8.2399 \\
<2.2 \times 10^{-16}\end{array}$ \\
\hline$D_{\text {Healthcare }}$ & 0.0435 & 0.2039 & 1.0000 & 0.0000 & 4.4778 & 18.0544 & $\begin{array}{c}8.2399 \\
<2.2 \times 10^{-16}\end{array}$ \\
\hline
\end{tabular}

To measure the strength of linear association between the regression variables, we estimated the Pearson's correlation coefficients. Table 2 shows the correlation matrix. It reveals that CC19, DC19, PB, and COVID-19 period variables $\left(D_{C 19}\right.$ 1st,$D_{C 19}$ 2nd,$D_{C 19}$ 3th , 
and $\left.D_{C 19 \_4 r d}\right)$ are positively correlated with the stock return (SR). While $M C$ and $D_{B F C 19}$ are negatively correlated with SR. Moreover, Table 2 reveals that the pairs of variables CC19, DC19 and MC, PB used in the regressions are highly and medium cross-correlated, respectively, and statistically significant at a $0.01 \%$ level.

Table 2. Correlation matrix of the models' variables.

\begin{tabular}{|c|c|c|c|c|c|c|c|c|c|c|}
\hline Variable & $S R$ & CC19 & DC19 & $M C$ & $P B$ & $D_{B F C 19}$ & $D_{C 19 \_1 s t}$ & $D_{C 19 \_2 n d}$ & $D_{C 19 \_3 r d}$ & $D_{C 19 \_4 t h}$ \\
\hline$S R$ & 1.00 & & & & & & & & & \\
\hline CC19 & 0.01 & 1.00 & & & & & & & & \\
\hline DC19 & 0.00 & $0.69^{* * * *}$ & 1.00 & & & & & & & \\
\hline$M C$ & -0.01 & 0.00 & 0.00 & 1.00 & & & & & & \\
\hline$P B$ & 0.01 & 0.02 & 0.01 & $0.34^{* * * *}$ & 1.00 & & & & & \\
\hline$D_{B F C 19}$ & $-0.04^{* * * *}$ & $-0.30^{* * * *}$ & $-0.26^{* * * *}$ & 0.01 & -0.01 & 1.00 & & & & \\
\hline$D_{C 19 \_1 s t}$ & 0.00 & -0.01 & -0.01 & $-0.04^{* * * *}$ & $-0.07^{* * * *}$ & $-0.11^{* * * *}$ & 1.00 & & & \\
\hline$D_{C 19} 2$ 2nd & 0.01 & $0.05^{* * * *}$ & $-0.03^{* *}$ & $-0.02 *$ & $-0.04^{* * * *}$ & $-0.11^{* * * *}$ & $-0.10^{* * * *}$ & 1.00 & & \\
\hline$D_{C 19} 3 r d$ & 0.01 & $0.09^{* * * *}$ & 0.01 & 0.01 & $0.02 * *$ & $-0.11^{* * * *}$ & $-0.10^{* * * *}$ & $-0.10^{* * * *}$ & 1.00 & \\
\hline$D_{C 19 \_4 t h}$ & 0.00 & 0.02 & $0.04^{* * * *}$ & $0.03 * *$ & $0.07 * * * *$ & $-0.07^{* * * *}$ & $-0.06^{* * * *}$ & $-0.06^{* * * *}$ & $-0.06^{* * * *}$ & 1.00 \\
\hline
\end{tabular}

Before running the regressions, a stationary test was required for the variables $S R$, CC19, DC19, MC, and PB included in the panel regression models. We used the MaddalaWu test on panel data for each of the variables $S R, M C$, and $P B$. The augmented DickeyFuller test was performed on the variables CC19 and DC19. Results are reported in Table 3. The null hypothesis that each of these variables contains a unit-root was rejected, therefore each of these variables are stationary.

We conducted some tests to determine if a pooled, fixed, or random effects model was more suitable for the panel data regression models. For all models, the pooled model gave a $p$-value of all variables higher than 0.05 . Consequently, the pooled model was not suitable for the studied models and therefore we moved towards either fixed or random effects panel data regression. To distinguish between fixed or random effects, the Hausman test for endogeneity was implemented to the models. The Hausman test showed a very low (highly significant) $p$-value of the test (less than $2.2 \times 10^{-16}$ ), which indicated that the null hypothesis saying that the individual random effects are exogenous is rejected, which makes the random effects inconsistent. Hence, we accepted the fixed effects specification were appropriate. Then, we implemented the VIF test to inspect the multicollinearity among independent variables. The VIF values of variables were less than 4 , meaning there was no multicollinearity. In addition, to test for the cross-sectional dependence in panels, the Breusch-Pagan LM test was implemented. The Breusch-Pagan LM test gave a $p$-value of all models less than $2.2 \times 10^{-16}$, therefore the null hypothesis was rejected, and the cross-sectional dependence was present. According to [54], cross-sectional dependence is a problem in macro panels with a long time series. This is not much of a problem in micro panels (for a few years' period and in a large number of cases). The Breusch-Godfrey test we used to check the serial correlation in the panel models, failing to reject the null hypothesis because the $p$-values were higher than 0.05. The Breusch-Pagan test, whose null hypothesis is homoskedasticity, was also used to check the panel data fixed effect regression models. The null hypothesis was rejected because $p$-values were less than $2.2 \times 10^{-16}$, thus hetersokedaticity was detected. Therefore, we needed to use clustered robust standard error to account for the serial correlation and heteroskedasticity, an applicable method for a dataset with a larger number of cross section and short time series [76]. 
Table 3. Maddala-Wu (MW) and Augmented Dickey-Fuller (ADF) unit-root tests.

\begin{tabular}{ccc}
\hline Variable & Statistic & $p$-Value \\
\hline$S R(\mathrm{MW})$ & 5052.10 & $2.2 \times 10^{-16}$ \\
$C C 19(\mathrm{ADF})$ & -69.48 & 0.01 \\
$D C 19(\mathrm{ADF})$ & -65.05 & 0.01 \\
$M C(\mathrm{MW})$ & 65.75 & 0.03 \\
$P B(\mathrm{MW})$ & 64.13 & 0.02 \\
\hline
\end{tabular}

\section{Discussions}

4.1. The Effects of the COVID-19 Pandemic on the Bulgarian Stock Market before the COVID-19 and in the First, Second, Third, and Fourth Pandemic Waves

Table 4 presents the panel data fixed effect regression results of Models 1 (a), (b), (c), (d), and (e). From this it can be seen that the growth rate of COVID-19 deaths per day in Bulgaria is significantly negatively correlated with the stock returns at significance levels of $1 \%$ and $5 \%$ in Model 1 (a) and Models 1 (b), (c), (d), and (e), respectively. Therefore, the hypothesis $\mathrm{H} 1$ on the negative influence of the growth rate in confirmed COVID-19 cases per day on the return of the companies traded on the Bulgarian Stock Exchange has not been confirmed. Hypothesis H2, regarding the negative effect of the growth rate in COVID-19 deaths per day on the return of the companies traded on the Bulgarian Stock Exchange, has been confirmed. These results are consistent with the results obtained from [12,39,57,77-79], confirming that the news about COVID-19 daily deaths has significantly harmed stock returns.

Table 4. Fixed effect regression of stock returns before the COVID-19 pandemic and in the four pandemic waves.

\begin{tabular}{|c|c|c|c|c|c|}
\hline Variable & Model 1 (a) & Model 1 (b) & Model 1 (c) & Model 1 (d) & Model 1 (e) \\
\hline \multirow{2}{*}{ CC19 } & 0.000099 & 0.000263 & 0.000275 & 0.000210 & 0.000274 \\
\hline & $(0.000174)$ & $(0.000183)$ & $(0.000174)$ & $(0.000193)$ & $(0.000181)$ \\
\hline \multirow{2}{*}{ DC19 } & $-0.000254^{* *}$ & -0.000188 * & -0.000192 * & -0.000154 * & -0.000202 * \\
\hline & $(0.000130)$ & $(0.000108)$ & $(0.000104)$ & $(0.000111)$ & (0.000106) \\
\hline \multirow{2}{*}{$M C$} & -0.022982 & -0.024835 & -0.024244 & -0.024225 & -0.024421 \\
\hline & (0.019749) & $(0.019850)$ & $(0.019631)$ & $(0.019417)$ & $(0.019489)$ \\
\hline \multirow{2}{*}{$P B$} & 0.005152 & 0.005519 & 0.005508 & 0.005478 & 0.005434 \\
\hline & $(0.004899)$ & (0.004835) & $(0.004827)$ & $(0.004817)$ & $(0.004789)$ \\
\hline$D_{B F C 19}$ & $\begin{array}{c}-0.003983 * \\
(0.002155)\end{array}$ & & & & \\
\hline$D_{C 19 \_1 s t}$ & & $\begin{array}{c}-0.002503 \\
(0.001828)\end{array}$ & & & \\
\hline$D_{C 19 \_2 n d}$ & & & $\begin{array}{c}-0.000523 \\
(0.001413)\end{array}$ & & \\
\hline$D_{C 19 \_3 r d}$ & & & & $\begin{array}{c}0.001914^{* *} \\
(0.000783)\end{array}$ & \\
\hline$D_{C 19 \_4 t h}$ & & & & & $\begin{array}{c}0.003221 * * \\
(0.001536)\end{array}$ \\
\hline F-statistic & 14.410000 & 3.657000 & 3.869000 & 5.954700 & 4.037800 \\
\hline$p$-value & $2.576 \times 10^{-06}$ & 0.014700 & 0.011470 & 0.001255 & 0.009446 \\
\hline
\end{tabular}

Note: The clustered-robust standard errors are reported in parentheses; ${ }^{*}$ and ${ }^{* *}$ presents significance level at $5 \%$ and $1 \%$, respectively.

In terms of company characteristics, the market capitalisation $(M C)$ and the price-tobook ratio $(P B)$ during pre- and COVID-19 pandemic periods are insignificant to stock returns, respectively.

The dummy variable $D_{B F C 19}$ is negative with a significance level of $5 \%$, showing that before the COVID-19 pandemic there was a negative effect on all chosen 23 companies' stock returns from the Bulgarian stock market.

The dummy variables $D_{C 19} 1$ st and $D_{C 19}$ 2nd shows that the relationship between the stock returns and the first two COVID-19 waves is insignificant and negative.

In contrast, the relationship between the chosen 23 companies' stock returns from the Bulgarian stock market and the next two COVID-19 waves is positive and significant at 
$1 \%$. The reason for these results may be based on the fact that investors' fears that the first and second second COVID-19 waves will hamper the production and business activities of enterprises for a long time did not materialise. Even during the first COVID-19 wave, investors were reassured by the authorities through the introduction of various business support programs. Between these two epidemic waves, the level of interest rates on savings in banks has dropped dramatically, a sign that cash flow is shifting to more profitable investment channels. Securities were the preferred choice of investment because investing in gold and real estate became unattractive due to the sharp rise in their prices.

Table 4 reveals that the F-test gave a $p$-value of all models less than the significance level (5\%), which means that all the coefficients in the Models 1 (a), (b), (c), (d), and (e) are different than zero.

\subsection{The Effects of COVID-19 Pandemic on the Bulgarian Stock Market and Various Economic} Sectors before the COVID-19 and in the First, Second, Third, and Fourth Pandemic Waves

Table 5 presents the panel data fixed effect regression results of Models 2, 3 (a), (b), (c), (d), and (e).

Model 2 results show that during the COVID-19 pandemic in Bulgaria, various economic sectors (information technology, industrials, real estate, consumer staples, financial, utilities, and healthcare) had different connections with the stock returns of the chosen 23 companies.

The COVID-19 pandemic had a positive effect with a significance level of $0.01 \%$ on the information technology sector. Therefore, the hypothesis H3 has been confirmed. The IT sector in Bulgaria is the sector that improved during the pandemic as the internet became the primary means of linking people for work, education, and other purposes. The pandemic had a negative and significance level of $0.01 \%$ effect on consumer staples and the industrial sectors, and affected the real estate, the utilities, and the financial sectors negatively with significance level of $1 \%$. The key reason for this phenomenon is that many firms in Bulgaria are facing bankruptcy due to high electricity and natural gas prices and this in turn has led to a high unemployment rate [80].

Model 3 (a) regression results show that stock returns in healthcare, information technology, utilities, and real estate sectors were negatively (with significance level of $0.01 \%, 0.1 \% 1 \%$, and $5 \%$, respectively) affected before the COVID-19 pandemic.

Model 3 (b) shows that the first COVID-19 pandemic wave had a positive effect on the stock performance of healthcare and consumer staples sectors with a significance level of $0.01 \%$. This first pandemic wave led to a dramatic rise in the use of masks, hand sanitisers, medicines, etc., and the panic buying of essential goods.

Model 3 (c) results show that during the second COVID-19 wave, the stock returns of the utilities sector had a negative effect with a significance level of $0.01 \%$, while information technology had a positive effect with a significance level of $5 \%$. During the second wave in Bulgaria, water consumption decreased due to an increase in its price as well as the onset of the winter season. During this period, the interest in information technology was high again due to the re-imposition of restrictive measures by the authorities in respect to epidemic control.

As can be seen in Model 3 (d), the third COVID-19 wave had a positive effect on the stock performance of the industrials and consumer staples sectors with a significance level of $0.01 \%$, while the healthcare sector had a negative effect with a significance level of $1 \%$, followed by real estate and information technology sectors having a positive effects with a significance level of $1 \%$ and $5 \%$, respectively. This finding confirmed that investors' increased confidence in the Bulgarian government's various business support programs, resulted in favourable results for industrials, consumer staples, and real estate stock market sectors.

Model 3 (e) shows that during the fourth COVID-19 wave, the stock returns of the consumer staples sector had a negative and significance effect of $0.1 \%$ and information technology had positive and a significance effect of $5 \%$. In this period, a sudden surge was 
observed in electricity and natural gas prices worldwide, which negatively affected the purchasing power of Bulgarian people.

Models 2, 3 (a), (b), (c), and (d) show that the effects of the growth rate in COVID-19 deaths per day in Bulgaria had a negative effect with a significance level of $1 \%$. The chosen 23 companies' stock returns in the Bulgarian stock market were most affected during the fourth COVID-19 pandemic wave when the number of daily reported deaths was the highest, confirming the significant effect of COVID-19 on the Bulgarian stock market.

Table 5 reveals that the F-test gave a $p$-value of all models less than the the significance level (5\%), which means that all the coefficients in the Models 2, 3 (a), (b), (c), (d), and (e) are different than zero.

Table 5. Fixed effect regression between stock returns and various economic sectors during and before the COVID-19 pandemic and the four pandemic waves.

\begin{tabular}{|c|c|c|c|c|c|c|}
\hline Variable & Model 2 & Model 3 (a) & Model 3 (b) & Model 3 (c) & Model 3 (d) & Model 3 (e) \\
\hline \multirow{2}{*}{ Intercept } & 0.005891 & 0.436268 & 0.473682 & 0.449103 & 0.449076 & 0.451734 \\
\hline & $(0.007230)$ & $(0.046216)$ & $(0.046316)$ & $(0.045525)$ & $(0.045180)$ & $(0.045437)$ \\
\hline \multirow{2}{*}{ CC19 } & 0.000301 & 0.000101 & 0.000262 & 0.000274 & 0.000209 & 0.000273 \\
\hline & (0.000183) & $(0.000176)$ & $(0.000216)$ & (0.000197) & $(0.000231)$ & $(0.000212)$ \\
\hline \multirow{2}{*}{ DC19 } & $-0.000169 * *$ & $-0.000189^{* *}$ & $-0.000203^{* *}$ & $-0.000193 * *$ & $-0.000154^{* *}$ & $-0.000252 * *$ \\
\hline & $(0.000086)$ & $(0.000103)$ & $(0.000077)$ & $(0.000072)$ & $(0.000084)$ & $(0.000074)$ \\
\hline \multirow{2}{*}{$M C$} & -0.000257 & -0.023867 & -0.025948 & -0.024628 & -0.024631 & -0.024763 \\
\hline & $(0.000402)$ & $(0.023415)$ & $(0.023310)$ & $(0.022510)$ & $(0.022110)$ & $(0.022310)$ \\
\hline \multirow{2}{*}{$P B$} & 0.000203 & 0.005258 & 0.005747 & 0.005657 & 0.005587 & 0.005487 \\
\hline & $(0.000118)$ & $(0.005849)$ & $(0.005750)$ & $(0.005701)$ & $(0.005611)$ & $(0.005581)$ \\
\hline \multirow[t]{2}{*}{$D_{I T}$} & $\begin{array}{c}0.001891 * * * * \\
(0.007231)\end{array}$ & & & & & \\
\hline & $-0.001019^{* * * *}$ & & & & & \\
\hline$D_{\text {Industrials }}$ & $(0.000107)$ & & & & & \\
\hline & $-0.001252^{* * *}$ & & & & & \\
\hline$D_{\text {RealEstate }}$ & $(0.000234)$ & & & & & \\
\hline & $-0.002103^{* * * *}$ & & & & & \\
\hline DonsumerStaples & $(0.000169)$ & & & & & \\
\hline & $-0.001555^{* *}$ & & & & & \\
\hline$D_{\text {Financial }}$ & $(0.000582)$ & & & & & \\
\hline & -0.000497 & & & & & \\
\hline Dutilities & $(0.000787)$ & & & & & \\
\hline & $-0.001907^{* * *}$ & & & & & \\
\hline$D_{\text {Healthcare }}$ & $(0.000465)$ & & & & & \\
\hline$D_{I T}$ & & $-0.012769 * * *$ & & & & \\
\hline$D_{B F C 19}$ & & $(0.002420)$ & & & & \\
\hline$D_{\text {Industrials }}$ & & -0.003098 & & & & \\
\hline$D_{B F C 19}$ & & $(0.002504)$ & & & & \\
\hline$D_{\text {RealEstate }}$ & & $-0.001811 *$ & & & & \\
\hline$D_{B F C 19}$ & & $(0.000819)$ & & & & \\
\hline$D_{\text {ConsumerStaples }}$ & & 0.000252 & & & & \\
\hline$D_{B F C 19}$ & & $(0.006310)$ & & & & \\
\hline$D_{\text {Financial }}$ & & -0.004295 & & & & \\
\hline$D_{B F C 19}$ & & $(0.002508)$ & & & & \\
\hline$D_{\text {Utilities }}$ & & -0.007460 ** & & & & \\
\hline$D_{B F C 19}$ & & $(0.002457)$ & & & & \\
\hline$D_{\text {Healthcare }}$ & & $-0.006000^{* * * *}$ & & & & \\
\hline$D_{B F C 19}$ & & $(0.000667)$ & & & & \\
\hline$D_{I T}$ & & & -0.010906 & & & \\
\hline$D_{C 19 \_1 s t}$ & & & $(0.009181)$ & & & \\
\hline$D_{\text {Industrials }}$ & & & -0.003834 & & & \\
\hline$D_{C 19 \_1 s t}$ & & & $(0.002710)$ & & & \\
\hline$D_{\text {Real Estate }}$ & & & -0.001370 & & & \\
\hline$D_{C 19} 1 s t$ & & & $(0.001780)$ & & & \\
\hline$D_{\text {ConsumerStaples }}$ & & & $0.000451^{* * * *}$ & & & \\
\hline$D_{C 19 \_1 s t}$ & & & $(0.000037)$ & & & \\
\hline$D_{\text {Financial }}$ & & & -0.000378 & & & \\
\hline$D_{C 19 \_1 s t}$ & & & $(0.001740)$ & & & \\
\hline$D_{\text {Utilities }}$ & & & -0.008718 & & & \\
\hline$D_{C 19 \_1 s t}$ & & & $(0.006710)$ & & & \\
\hline$D_{\text {Healthcare }}$ & & & $0.005332^{* * * *}$ & & & \\
\hline$D_{C 19 \_1 s t}$ & & & $(0.000788)$ & & & \\
\hline
\end{tabular}


Table 5. Cont.

\begin{tabular}{|c|c|c|c|c|c|c|}
\hline Variable & Model 2 & Model 3 (a) & Model 3 (b) & Model 3 (c) & Model 3 (d) & Model 3 (e) \\
\hline$D_{I T}$ & & & & 0.003953 * & & \\
\hline$D_{C 19 \_2 s t}$ & & & & $(0.001921)$ & & \\
\hline$D_{\text {Industrials }}$ & & & & -0.001787 & & \\
\hline$D_{C 19 \_2 s t}$ & & & & $(0.002720)$ & & \\
\hline$D_{\text {RealEstate }}$ & & & & -0.001711 & & \\
\hline$D_{C 19} 2 s t$ & & & & $(0.002181)$ & & \\
\hline$D_{\text {ConsumerStaples }}$ & & & & -0.001443 & & \\
\hline$D_{C 19} 2 s t$ & & & & $(0.002681)$ & & \\
\hline$D_{\text {Financial }}$ & & & & 0.001059 & & \\
\hline$D_{C 19 \_2 s t}$ & & & & $(0.001200)$ & & \\
\hline$D_{\text {Utilities }}$ & & & & $-0.001932^{* * * *}$ & & \\
\hline$D_{\text {C19_2st }}$ & & & & 0.000174 & & \\
\hline$D_{\text {Healthcare }}$ & & & & 0.000273 & & \\
\hline$D_{C 19 \_2 s t}$ & & & & 0.000677 & & \\
\hline$D_{I T}$ & & & & & 0.008687 * & \\
\hline$D_{\text {C19_3st }}$ & & & & & (0.004321) & \\
\hline$D_{\text {Industrials }}$ & & & & & $0.002141^{* * * *}$ & \\
\hline$D_{C 19} 3 s t$ & & & & & $(0.000156)$ & \\
\hline$D_{\text {RealEstate }}$ & & & & & $0.000981^{* *}$ & \\
\hline$D_{C 19} 3 s t$ & & & & & $(0.000268)$ & \\
\hline$D_{\text {ConsumerStaples }}$ & & & & & $0.002048^{* * * *}$ & \\
\hline$D_{C 19} 3 s t$ & & & & & $(0.000315)$ & \\
\hline$D_{\text {Financial }}$ & & & & & -0.000306 & \\
\hline$D_{C 19} 3 s t$ & & & & & $(0.000761)$ & \\
\hline$D_{\text {Utilities }}$ & & & & & 0.003898 & \\
\hline$D_{C 19 \_3 s t}$ & & & & & $(0.002481)$ & \\
\hline$D_{\text {Healthcare }}$ & & & & & $-0.001845^{* *}$ & \\
\hline$D_{C 19 \_3 s t}$ & & & & & $(0.000605)$ & \\
\hline$D_{I T}$ & & & & & & 0.008160 * \\
\hline$D_{C 19 \_4 s t}$ & & & & & & $(0.003810)$ \\
\hline$D_{\text {Industrials }}$ & & & & & & 0.005668 \\
\hline$D_{C 19} 4 s t$ & & & & & & $(0.004561)$ \\
\hline$D_{\text {RealEstate }}$ & & & & & & 0.003196 \\
\hline$D_{C 19} 4 s t$ & & & & & & $(0.002631)$ \\
\hline$D_{\text {ConsumerStaples }}$ & & & & & & $-0.000458^{* * *}$ \\
\hline$D_{C 19} 4 s t$ & & & & & & $(0.000121)$ \\
\hline$D_{\text {Financial }}$ & & & & & & -0.000134 \\
\hline$D_{C 19 \_4 s t}$ & & & & & & $(0.002590)$ \\
\hline$D_{\text {Utilities }}$ & & & & & & 0.003566 \\
\hline$D_{C 194 s t}$ & & & & & & $(0.003861)$ \\
\hline$D_{\text {Healthcare }}$ & & & & & & 0.002356 \\
\hline$D_{C 19} 4 s t$ & & & & & & $(0.001231)$ \\
\hline $\mathrm{F}$-statistic & 14.361513 & 28.617841 & 62.090132 & 58.806180 & 44.118682 & 79.109991 \\
\hline$p$-value & 0.009525 & $<2.2 \times 10^{-16}$ & $<2.2 \times 10^{-16}$ & $<2.2 \times 10^{-16}$ & $<2.2 \times 10^{-16}$ & $<2.2 \times 10^{-16}$ \\
\hline
\end{tabular}

Note: The clustered-robust standard errors are reported in parentheses; ${ }^{*}, * *, * * *$, and ${ }^{* * * *}$ presents significance level at $5 \%, 1 \%, 0.1 \%$, and $0.01 \%$, respectively.

\section{Conclusions}

The COVID-19 pandemic outbreak and its spread almost globally has negatively impacted the economy. The COVID-19 pandemic has affected also the stock markets, as it initially manifested itself on the largest stock markets in the world, then, it was transmitted to other smaller markets. To the best of our knowledge, no study has estimated the effects of the COVID-19 pandemic on the Bulgarian stock market.

The purpose of the paper was to provide the first empirical piece of research analysing the effects of the COVID-19 pandemic on the Bulgarian stock market before its onset as well as the first, second, third, and fourth pandemic waves. For this purpose, we used a fixed effect panel data regression model for the stock returns of 23 companies listed on the Bulgarian Stock Exchange from 2 January 2020 to 16 November 2021. We analysed the evolution of stock returns under the influence of variables reflecting the spread of COVID-19 in Bulgaria (the growth rate in confirmed COVID-19 cases per day, growth rate in COVID-19 deaths per day), as well as of the variables related to the period before the COVID-19 pandemic in Bulgaria and the four pandemic waves. The analysis also included 
the variables describing some firm-specific characteristics, such as market capitalisation and the price-to-book ratio. Moreover, this paper studied the effects of the COVID-19 pandemic in Bulgaria on various economic sectors before its onset and in the four pandemic waves.

The study showed that the growth rate of COVID-19 deaths per day in Bulgaria had a negative effect on the stock returns, having the strongest influence on them in the fourth pandemic wave. Company characteristics during pre- and COVID-19 pandemic periods were insignificant to stock returns. In addition, our results showed that stock returns in healthcare, IT, utilities, and real estate sectors were negatively affected before the COVID-19 pandemic while the first COVID-19 pandemic wave had a positive effect on healthcare and consumer staples sectors. During the second COVID-19 wave, the stock returns of the IT sector had a positive effect, while the utilities sector had a negative effect. The third COVID-19 wave had a positive effect on industrials and consumer staples sectors, while healthcare, real estate, and IT sectors had a negative one. During the fourth COVID-19 wave, the stock returns of the IT sector had a positive effect and the consumer staples sector showed a negative effect.

The authors believe that this study will help investors to predict which sectors will be profitable throughout other similar pandemics.

Author Contributions: The authors L.D., M.I. and M.V. contributed equally to this work. All authors have read and agreed to the published version of the manuscript.

Funding: The authors have received no funding for this work.

Data Availability Statement: The data that support the findings of this study are available from the corresponding author, upon reasonable request.

Conflicts of Interest: There is no conflict of interest.

\section{References}

1. WHO. World Health Organization Pneumonia of Unknown Cause-China. 2020. Available online: https://www.who.int/csr/ don/05-january-2020-pneumonia-of-unkown-cause-china/en/ (accessed on 30 December 2021).

2. Blofield, M.; Hoffmann, B.; Llanos M. Assessing the Political and Social Impact of the COVID-19 Crisis in Latin America. Available online: https:/ / www.ssoar.info/ssoar/handle/document/67260 (accessed on 29 December 2021).

3. Huang, C.; Wang, Y.; Li, X.; Ren, L.; Zhao, J.; Hu, Y.; Zhang, L.; Fan, G.; Xu, J.; Gu, X.; et al. Clinical features of patients infected with 2019 novel coronavirus in Wuhan, China. Lancet 2020, 395, 497-506. [CrossRef]

4. Alon, T.M.; Olmstead-Rumsey, M.; Tertilt, M. The impact of COVID19 on gender equality. NBER 2020. [CrossRef]

5. McKibbin, M.J.; Fernando, F. The global macroeconomic impacts of COVID-19: Seven scenarios. CAMA 2020. [CrossRef]

6. Bulgaria in Third Place in EU-EEA in COVID-19 Mortality. Available online: https://sofiaglobe.com/2020/11/19/bulgaria-inthird-place-in-eu-eea-in-covid-19-mortality/ (accessed on 5 January 2022).

7. Bulgaria Reported a Record Number of Daily Coronavirus Deaths on Tuesday (9 November 2021). Available online: https: //www.euractiv.com/section/health-consumers/news/bulgarias-daily-covid-19-deaths-rise-to-record-high/ (accessed on 6 January 2022).

8. World Health Organization: Bulgaria Situation. Available online: https://covid19.who.int/region/euro/country/bg (accessed on 6 January 2022).

9. Akhtaruzzaman, M.; Boubaker, S.; Sensoy, A. Financial contagion during COVID-19 crisis. Financ. Res. Lett. 2020, 38, 101604. [CrossRef]

10. Barrafrem, K.; Västfjäll, D.; Tinghög, G. Financial well-being, COVID-19, and the financial better-than-average-effect. J. Behav. Exp. Finance 2020, 28, 100410. [CrossRef]

11. Baek, S.; Mohanty, S.K.; Glambosky, M. COVID-19 and stock market volatility: An industry level analysis. Finance Res. Lett. 2020, 37, 101748. [CrossRef]

12. Al-Awadhi, A.M.; Alsaifi, K.; Al-Awadhi, A.; Alhammadi S. Death and contagious infectious diseases: Impact of the COVID-19 virus on stock market returns. J. Behav. Exp. Financ. 2020, 27, 100326. [CrossRef]

13. Takyi, P.O.; Bentum-Ennin, I. The impact of COVID-19 on stock market performance in Africa: A Bayesian structural time series approach. J. Econ. Bus. 2021, 115, 105968. [CrossRef] [PubMed]

14. Hung, D.V.; Hue, N.T.M.; Duong, V.T. The impact of COVID-19 on stock market returns in Vietnam. J. Risk Financial Manag. 2021, 14, 441. [CrossRef]

15. Hatmanu, M.; Cautisanu, C. The Impact of COVID-19 Pandemic on Stock Market: Evidence from Romania. Int. J. Environ. Res. Public Health 2021, 18, 9315. [CrossRef]

16. Chevallier, J. COVID-19 Pandemic and Financial Contagion. J. Risk Financ. Manag. 2020, 13, 309. [CrossRef] 
17. Naeem, M.A.; Sehrish, S.; Costa M.D. COVID-19 pandemic and connectedness across financial markets. J. Chin. Econ. Foreign Trade Stud. 2021, 14, 60-73. [CrossRef]

18. Insaidoo, M.; Arthur, L.; Amoako, S.; Andoh, F.K. Stock market performance and COVID-19 pandemic: Evidence from a developing economy. Pac. Account. Rev. 2021, 33, 165-178. [CrossRef]

19. Lee, K.-J.; Lu, S.-L. The Impact of COVID-19 on the Stock Price of Socially Responsible Enterprises: An Empirical Study in Taiwan Stock Market. Int. J. Environ. Res. Public Health 2021, 18, 1398. [CrossRef]

20. Batrancea, L. An econometric approach regarding the impact of fiscal pressure on equilibrium: Evidence from electricity, gas and oil companies listed on the New York stock exchange. Mathematics 2021, 9, 630. [CrossRef]

21. Yan, C. COVID-19 Outbreak and Stock Prices: Evidence from China. Available online: http://dx.doi.org/10.2139/ssrn.3574374 (accessed on 3 February 2022).

22. Lo, G.D.; Basséne, T.; Séne, B. COVID-19 And the african financial markets: Less infection, less economic impact? Finance Res Lett. 2021, 45, 102148.

23. Liu, Z.; Huynh, T.L.D.; Dai, P.-F. The impact of COVID-19 on the stock market crash risk in China. Res. Int. Bus. Finance 2021, 57, 101419. [CrossRef]

24. Samitas, A.; Kampouris, E.; Polyzos, S. Covid-19 pandemic and spillover effects in stock markets: A financial network approach Int. Rev. Financ. Anal. 2022, 80, 102005. [CrossRef]

25. Liu, F.; Kong, D.; Xiao, Z.; Zhang, X.; Zhou, A.; Qi, J. Effect of economic policies on the stock and bond market under the impact of COVID-19. JSSR 2022, 3, 24-38. [CrossRef]

26. Rehman, M.U.; Kang, S.H.; Ahmad, N.; Vo, X.V. The impact of COVID-19 on the G7 stock markets: A time-frequency analysis North Am. J. Econ. Financ. 2021, 58, 101526. [CrossRef]

27. Li, Y.; Zhuang, X.; Wang, J.; Dong, Z. Analysis of the impact of COVID-19 pandemic on G20 stock markets. North Am. J. Econ. Finance 2021, 58, 101530. [CrossRef]

28. Chowdhury, E.K.; Khan, I.I.; Dhar, B.K. Catastrophic impact of Covid-19 on the global stock markets and economic activities. Bus. Soc. Rev. 2021, 1-24. [CrossRef]

29. Youssef, M.; Mokni, K.; Ajmi, A.N. Dynamic connectedness between stock markets in the presence of the COVID-19 pandemic: Does economic policy uncertainty matter? Financ. Innov. 2021, 7, 13. [CrossRef] [PubMed]

30. Szczygielski, J.J.; Bwanya, P.R.; Charteris, A.; Brzeszczyński, J. The only certainty is uncertainty: An analysis of the impact of COVID-19 uncertainty on regional stock markets. Finance Res. Lett. 2021, 43, 101945. [CrossRef] [PubMed]

31. Nian, R.; Xu, Y.; Yuan, Q.; Feng, C.; Lendasse, A. Quantifying time-frequency co-movement impact of COVID-19 on U.S. and China stock market toward investor sentiment index. Front. Public Health. 2021, 9, 727047. [CrossRef]

32. Zehri, C. Stock market comovements: Evidence from the COVID-19 pandemic. J. Econ. Asymmetries 2021, 24, e00228. [CrossRef]

33. Zhang, Y.; Mao, J. COVID-19's impact on the spillover effect across the Chinese and U.S. stock markets. Finance Res. Lett. 2022, 102684. [CrossRef]

34. Camba, A.L.; Camba, A.C., Jr. The effect of Covid-19 pandemic on the Philippine stock Exchange, Peso-Dollar rate and retail price of diesel. J. Asian Finance Econ. Bus. 2020, 7, 543-553. [CrossRef]

35. Liu, H.; Manzoor, A.; Wang, C.; Zhang, L.; Manzoor, Z. The COVID-19 outbreak and afected countries stock markets response. Int. J. Environ. Res. Public Health 2020, 17, 2800. [CrossRef]

36. Xu, L. Stock Return and the COVID-19 pandemic: Evidence from Canada and the US. Finance Res. Lett. 2021, $38,101872$. [CrossRef]

37. Orhun, E. The impact of COVID-19 global health crisis on stock markets and understanding the cross-country effects. Pac. Account. Rev. 2021, 33, 142-159.

38. Ryandono, M.N.H.; Muafi, M.; Guritno, A. Sharia Stock Reaction Against COVID-19 Pandemic: Evidence from Indonesian Capital Markets. J. Asian Finance Econ. Bus. 2021, 8, 697-710.

39. Utomo, C.D.; Hanggraeni, D. The Impact of COVID-19 Pandemic on Stock Market Performance in Indonesia. J. Asian Finance Econ. Bus. 2021, 8, 777-784.

40. Singh, G.; Shaik, M. The Short-Term Impact of COVID-19 on Global Stock Market Indices. Contemp. Econ. 2021, 15, 1-18. [CrossRef]

41. Ashraf, B.N. Stock markets'reaction to COVID-19: Cases or fatalities? Res. Int. Bus. Finance 2020, 54, 101249. [CrossRef]

42. Baig, A.S.; Butt, H.A.; Haroon, O.; Rizvi, A. Deaths, panic, lockdowns and US equity markets: The case of COVID-19 pandemic. Financ. Res. Lett. 2021, 38, 101701. [CrossRef]

43. Udeaja, E.A.; Isah, K.O. Stock markets' reaction to COVID-19: Analyses of countries with high incidence of cases/deaths in Africa. Sci. Afr. 2022, 15, e01076. [CrossRef]

44. Bahrini, R.; Filfilan, A. Impact of the novel coronavirus on stock market returns: Evidence from GCC countries. Quant. Financ. 2020, 4, 640-652. [CrossRef]

45. Mazur, M.; Dang, M.; Vega, M. COVID-19 and the March 2020 stock market crash. Evidence from S\&P1500. Financ. Res. Lett. 2020, 38, 101690.

46. Anh, D.L.T.; Gan, C. The impact of the COVID-19 lockdown on stock market performance: evidence from Vietnam. J. Econ. Stud. 2021, 48, 836-851. [CrossRef] 
47. Atassi, H.; Yusuf, N. The Effect of COVID-19 on Investment Decisions in Saudi Stock Market. J. Asian Finance Econ. Bus. 2021, 8 , 797-807.

48. Alam, M.M.; Wei, H.; Wahid, A.N.M. COVID-19 outbreak and sectoral performance of the Australian stock market: An event study analysis. Aust. Econ. Pap. 2020, e12215. [CrossRef] [PubMed]

49. He, P.; Sun, Y.; Zhang, Y.; Li, T. COVID-19's impact on stock prices across different sectors-An event study based on the Chinese stock market. Emerg. Mark. Financ. 2020, 56, 2198-2212. [CrossRef]

50. Herwany, A.; Febrian, E.; Anwar, M.; Gunardi, A. The Influence of the COVID-19 Pandemic on Stock Market Returns in Indonesia Stock Exchange. Emerg. Mark. Financ. 2021, 8, 39-47.

51. The Humanitarian Data Exchange. Available online: https:/ / covid19.who.int/WHO-COVID-19-global-data.csv (accessed on 24 November 2021).

52. Elhorst, J.P. Spatial Panel Data Models. In Spatial Econometrics; Springer: Berlin/Heidelberg, Germany, $2014 ;$ pp. 37-93.

53. Hsiao, C. Why panel data? Singapore Econ. Rev. 2005, 50, 143-154. [CrossRef]

54. Baltagi, B.H. Econometric Analysis of Panel Data, 3rd ed.; John Wiley \& Sons: Hoboken, NJ, USA, 2008.

55. Wooldridge, J.M. Econometric Analysis of Cross Section and Panel Data, 2nd ed.; The MIT Press: Cambridge, MA, USA, 2010.

56. Hsiao, C. Analysis of Panel Data, 2nd ed.; Cambridge University Press: Cambridge, UK, 2014.

57. Rao, P.; Goyal, N.; Kumar, S.; Hassan, M.K.; Shahimi, S. Vulnerability of financial markets in India: The contagious effect of COVID-19. Res. Int. Bus. Finance 2021, 58, 101462. [CrossRef]

58. Sun, Y.; Wu, M.; Zeng, X.; Peng, Z. The impact of COVID-19 on the Chinese stock market: Sentimental or substantial? Finance Res. Lett. 2021, 38, 101838. [CrossRef]

59. Seddighi, H.; Lawler, K.A.; Katos, A.V. Econometrics: A Practical Approach, 1st ed.; Routledge: New York, NY, USA, 2000.

60. Greene, W.H. Econometric Analysis, 3rd ed.; Macmillan Publishing Company: New York, NY, USA, 1997.

61. Maddala, G.S.; Wu, S. A comparative study of panel data unit root tests and a simple alternative. Oxf. Bull. Econ. Stat. 1999, 61, 631-652. [CrossRef]

62. Hausman, J.A. Specification Tests in Econometrics. Econometrica 1978, 46, 1251-1271. [CrossRef]

63. Breusch, T.S.; Pagan, A.R. The Lagrange Multiplier test and its application to model specifications in econometrics. Rev. Econ. Stud. 1980, 47, 239-253. [CrossRef]

64. Breusch, T.S. Testing for Autocorrelation in Dynamic Linear Models. Aust. Econ. Pap. 1978, 17, 334-355. [CrossRef]

65. Godfrey, L.G. Testing Against General Autoregressive and Moving Average Error Models when the Regressors Include Lagged Dependent Variables. Econometrica 1978, 46, 1293-1301. [CrossRef]

66. Breusch, T.S.; Pagan, A.R. A Simple Test for Heteroskedasticity and Random Coefficient Variation. Econometrica 1979, 47, 1287-1294. [CrossRef]

67. Raifu, I.A.; Kumeka, T.T.; Aminu, A. Reaction of stock market returns to COVID-19 pandemic and lockdown policy: Evidence from Nigerian frms stock returns. Future Bus. J. 2021, 7, 35. [CrossRef]

68. Yong, J.N.C.; Ziaei, S.M.; Szulczyk, K.R. The impact of Covid-19 pandemic on stock market return volatility: Evidence from Malaysia and Singapore. Asian Econ. Financ. Rev. 2021, 11, 191-204. [CrossRef]

69. Banerjee, A.K. Futures market and the contagion effect of COVID-19 syndrome. Finance Res. Lett. 2021, 43, 102018. [CrossRef]

70. Fakhfekh, M.; Jeribi, A.; Salem, M.B. Volatility dynamics of the Tunisian stock market before and during the COVID-19 outbreak: Evidence from the GARCH family models. Int. J. Finance Econ. 2021, 1-14. [CrossRef]

71. Ftiti, Z.; Ameur, H.B.; Louhichi, W. Does non-fundamental news related to COVID-19 matter for stock returns? Econ. Model. 2021, 99, 105484. [CrossRef]

72. Gherghina, S..C.; Armeanu, D.S.; Joldes, C.C. COVID-19 Pandemic and Romanian Stock Market Volatility: A GARCH Approach. J. Risk Financ. Manag. 2021, 14, 341. [CrossRef]

73. Yu, X.; Xiao, K.; Liu, J. Dynamic co-movements of COVID-19 pandemic anxieties and stock market returns. Finance Res. Lett. 2021, 102219. [CrossRef]

74. Zhang, W.; Hamori, S. Crude oil market and stock markets during the COVID-19 pandemic: Evidence from the US, Japan, and Germany. Int. Rev. Financial Anal. 2021, 74, 101702. [CrossRef]

75. Yousfi, M.; Zaied, Y.B.; Cheikh, N.B.; Lahouel, B.B.; Bouzgarrou, H. Effects of the COVID-19 pandemic on the US stock market and uncertainty: A comparative assessment between the first and second waves. Technol. Forecast. Soc. Chang. 2021, 167, 120710. [CrossRef]

76. Wooldridge, J.M. Introductory Econometrics A Modern Approach, 5th ed.; South-Western Pub: Mason, OH, USA, 2013.

77. Erdem, O. Freedom and stock market performance during Covid-19 outbreak. Finance Res. Lett. 2020, 36, 101671. [CrossRef] [PubMed]

78. Salisu, A.A.; Narayan, X.V. Predicting stock returns in the presence of COVID-19 pandemic: The role of health news. Int. Rev. Financ. Anal. 2020, 71, 101546. [CrossRef]

79. Robin, R. Death Infectious: Impact of the Coronavirus Disease (COVID-19) on Stock Returns. JEBAV 2021, 24, 95-104. [CrossRef]

80. National Social Security Institute. Available online: https://www.nssi.bg/ (accessed on 20 December 2021). 